Пензеник О.А., Миронюк І.С., Кручаниця В.В.

\title{
Результати вивчення думки лікарів третинного рівня надання медичної допомоги щодо окремих питань організації реабілітаційної допомоги паціснтам у закладах охорони здоров'я
}

\author{
ДВНЗ «Ужгородський національний університет», м. Ужгород, Україна
}

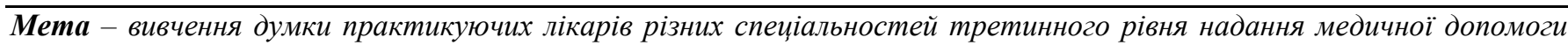
щзодо їх відношення до реабілітації пацієнтів у закладах охорони здоров'я, де вони працюють і оцінки ефективності організації даного напрямку роботи.

Об'єкт і методи. Об'єктом дослідження виступила система організації відновного лікування та реабілітаційної допомоги пацієнтам в закладах охорони здоров'я третинного рівня надання медичної допомоги в Закарпатській області. Методи дослідження: системний підхід і системний аналіз; соиіологічний метод, статистичний метод.

Результати. За результатами проведеного опитування 70 лікарів-спеціалістів виявлено, щзо усі знайомі з принципами організації відновного лікування хворих та формуванням реабілітаційних програм. Хоча, лише 14,3\% опитаних лікарів визнають здатність самостійно сформувати ефективну програму реабілітації. Найвищі рівні розуміння та прихильності до необхідності впровадження програм реабілітації в закладах, де вони працюють проявили кардіологи, невропатологи та акушер-гінекологи (4,0-4,3 бали із 5 можливих). Оцінка рівня ефективності організації відновного лікування та реабілітації у закладах охорони здоров'я лікарями визначена 3,74 бали з 4 максимально можливих за категорією «часткового забезпечення певного аспекту відновного лікування та реабілітаційних послуг».

Висновки. Загальний рівень прихильності опитаних лікарів до відновного лікування та необхідності реабілітаційної допомоги загалом є достатньо високим. На думку опитаних лікарів, система відновного лікування та реабілітації в закладах охорони здоров'я, де вони працюють, потребує вдосконалення.

Ключові слова: реабілітаџійна допомога, заклади охорони здоров'я третинного рівня, соиіологічне дослідження, лікарі різних спечіальностей.

\section{Вступ}

$\mathrm{B}$ иражений медицини

інтерес фахівців практичної до системи реабілітаційної допомоги пацієнтам зумовлена усвідомленням світовим медичним співтовариством недостатньої ефективності зусиль клінічної медицини в справі відновлення та компенсації втрачених у процесі хвороби чи після перенесених травм фізіологічних функцій організму [1].

Проблема створення ефективної системи реабілітації в Україні та професійної підготовки фахівців, що працюють в сфері відновлення здоров'я і в профільних центрах, $\epsilon$ складною i актуальною для українського суспільства. За статистичними даними в Україні зареєстровано понад 2,7 млн інвалідів, приблизно половина 3 них - особи працездатного віку, що набуває великої економічної значущості та завдає чималих збитків фінансовій системі держави [2].

На думку фахівців в галузі медичної реабілітації, за 20 останніх років загальна потреба в медичній реабілітації зросла в 5,4 рази. Дослідниками доведено, що медична реабілітація $\epsilon$ різнодоступною для хворих 3 різною патологією. При хворобах опорно-рухового апарату вона використовується у 5,7 разів відносно частіше, порівняно 3 іншими хворобами. Водночас суттєво рідше медична реабілітація використовується стосовно хвороб системи кровообігу (в 2,7 рази), хвороб органів дихання (в 6,7 разів), хвороб органів травлення (в 2,7 рази), що потребує прискореного розвитку іiі адекватних методів і засобів 3 метою більш позитивного впливу на громадське здоров'я [3]. На сьогодні вагомою залишається проблема кадрового забезпечення реабілітації, яке не досягає світових та європейських стандартів. Питання про те, як найкраще організувати службу реабілітації, дискутується протягом тривалого часу. Деякі країни здійснюють програми, що передбачають створення спеціалізованих відділів реабілітації (спеціалізований підхід). Інші країни зробили наголос на покращенні підготовки студентів-медиків за рахунок інтегрованого навчання методів реабілітації в поєднанні із профілактичними та лікувальними аспектами інвалідності. Такий підхід має за мету спонукати всіх лікарів до здійснення реабілітації як невід'ємної частини їх повсякденної роботи (неспеціалізований підхід). Слід зазначити, що як спеціалізований, так і неспеціалізований підходи довели свою цінність. Тому при реорганізації медичної допомоги та підготовки кадрів у вищих навчальних закладах, яка назріла в Україні, слід раціонально використовувати обидва підходи [4].

Мета роботи - вивчити думку практикуючих лікарів різних спеціальностей третинного рівня надання медичної допомоги щодо їх відношення до необхідності відновного лікування та реабілітації пацієнтів у закладах охорони здоров'я, де вони працюють і оцінки ефективності організації даного напрямку роботи. 


\section{Об’скт і методи дослідження}

Об'єктом дослідження виступила система організації відновного лікування та реабілітаційної допомоги пацієнтам в закладах охорони здоров'я третинного рівня надання медичної допомоги в Закарпатській області. Предметом дослідження стали результати опитування лікарів третинної ланки щодо організації відновного лікування в медичних закладах третинного рівня. Для досягнення мети дослідження були застосовані такі методи дослідження: системний підхід і системний аналіз використовувався на всіх етапах дослідження; соціологічний метод, статистичний метод для математичної обробки отриманих даних. Соціологічне дослідження являло собою разове вибіркове соціологічне дослідження та охоплювало третинний (високоспеціалізований) рівень надання медичної допомоги і проводитиметься серед лікарів-спеціалістів багатопрофільного закладу охорони здоров'я. Для опитування цільової групи респондентів було використано спеціально розроблену анкету (табл. 1).

Таблиияя 1

Анкета оцінки можливості застосування відновного лікування та реабілітації на різних етапах лікування паціснтів

\begin{tabular}{|c|c|c|}
\hline № & Питання & Варіанти відповідей \\
\hline 1 & $\begin{array}{l}\text { Чи знайомі Ви з принципами } \\
\text { організації відновного лікування } \\
\text { хворих та формуванням } \\
\text { реабілітаційних програм? } \\
\text { Виберіть одну відповідь }\end{array}$ & $\begin{array}{l}\text { a) Нi, принципи організації відновного лікування мені не відомі } \\
\text { b) Так, відомі, але я не можу самостійно сформувати ефективну } \\
\text { реабілітаційну програму } \\
\text { с) Так, відомі, і я можу самостійно сформувати ефективну } \\
\text { програму реабілітації }\end{array}$ \\
\hline 2 & $\begin{array}{l}\text { Чи застосовується відновне } \\
\text { лікування для хворих у тому } \\
\text { закладі, в якому Ви працюєте? } \\
\text { Виберіть одну відповідь }\end{array}$ & $\begin{array}{l}\text { a) Нi, не застосовується } \\
\text { b) Застосовуються певні елементи відновного лікування (масаж, } \\
\text { ЛФК, фізіотерапевтичні процедури) } \\
\text { с) Застосовуються в повному об’ємі реабілітаційні програми для } \\
\text { хворих за показаннями }\end{array}$ \\
\hline 3 & $\begin{array}{l}\text { Чи повинні реалізовуватись } \\
\text { програми реабілітації пацієнтів } \\
\text { (за показаннями) на третинному } \\
\text { рівні надання медичної допомоги? } \\
\text { Виберіть одну відповідь }\end{array}$ & $\begin{array}{l}\text { a) Так, саме на третинному рівні ефективність реабілітаційних } \\
\text { програм має максимальну ефективність } \\
\text { b) Так, і не тільки на третинному, тому що реабілітаційна програма } \\
\text { повинна охоплювати весь період лікування } \\
\text { c) Нi, реабілітаційні програми слід починати по завершенні } \\
\text { клінічного лікування } \\
\text { d) Нi, реабілітаційні програми взагалі не мають суттєвого впливу } \\
\text { на лікувальний процес }\end{array}$ \\
\hline 4 & $\begin{array}{l}\text { Який принцип реалізації } \\
\text { відновного лікування в рамках } \\
\text { третинного рівня надання медичної } \\
\text { допомоги вважаєте максимально } \\
\text { ефективним? } \\
\text { Виберіть одну відповідь }\end{array}$ & $\begin{array}{l}\text { a) На базі фізіотерапевтичного відділення закладу у якості } \\
\text { доповнюючого фактору до процесу клінічного лікування } \\
\text { b) На базі реабілітаційного відділення закладу у поєднанні } 3 \\
\text { клінічним лікуванням } \\
\text { c) На базі реабілітаційного центру по завершенні клінічного } \\
\text { лікування }\end{array}$ \\
\hline 5 & $\begin{array}{l}\text { Який спеціаліст повинен визначати } \\
\text { необххдність формування } \\
\text { реабілітаційних програм? } \\
\text { Виберіть одну відповідь }\end{array}$ & $\begin{array}{l}\text { a) Реабілітаційне лікування не має суттєвого значення } \\
\text { b) Лікуючий лікар-клініцист у процесі лікування } \\
\text { c) Спеціаліст-реабілітолог, якого слід залучати паралельно з } \\
\text { клінічним лікуванням } \\
\text { d) Спеціаліст-реабілітолог, якого слід залучати після завершення } \\
\text { клінічного лікування }\end{array}$ \\
\hline 6 & $\begin{array}{l}\text { Чи достатнє охоплення пацієнтів } \\
\text { медичною реабілітацією у вашому } \\
\text { закладі? Виберіть одну відповідь }\end{array}$ & $\begin{array}{ll}\text { a) } & \text { Так } \\
\text { b) } & \text { Частково } \\
\text { c) } & \mathrm{Hi}\end{array}$ \\
\hline 7 & $\begin{array}{l}\text { Чи достатня кількість спеціалістів } \\
\text { з відновного лікування праціює } \\
\text { у Вашому закладі? } \\
\text { Виберіть одну відповідь }\end{array}$ & $\begin{array}{l}\text { Так, потреби хворих забезпечуються } \\
\text { Фахівці є, але слід збільшити їх кількість } \\
\text { Ні, фахівців не достатньо }\end{array}$ \\
\hline 8 & $\begin{array}{l}\text { Хто повинен оцінювати ефективність } \\
\text { медичної реабілітації? } \\
\text { Виберіть одну відповідь }\end{array}$ & $\begin{array}{ll}\text { a) } & \text { Лікар-клініцист } \\
\text { b) } & \text { Спеціаліст-реабілітолог } \\
\text { c) Хворий та його оточення } \\
\text { d) } \\
\text { Всі учасники програми реабілітації }\end{array}$ \\
\hline
\end{tabular}


9 Чи вважаєте ви що система відновного лікування в комплексі надання медичних послуг у Вашому закладі організована ефективно?

Виберіть одну відповідь b) У нашому закладі не проводиться відновне лікування

c) Так, система відновного лікування організована ефективно

d) $\mathrm{Hi}$, система відновного лікування потребує вдосконалення
Питання анкети охоплюють такі проблеми, як обізнаність лікарів у принципах організації відновного лікування; роль і місце реабілітаційних програм у закладах, де вони працюють; можливі шляхи покращення відновного лікування. Фахівці-реабілітологи в контексті даного дослідження розглядаються як спеціалісти фізичної та реабілітаційної медицини у складі міждисциплінарних робочих команд - фізичний терапевт, ерготерапевт, лікар фізичної та реабілітаційної медицини.

За своєю направленістю запитання анкети умовно поділено на дві групи. Перша група запитань стосується організації відновного лікування та реабілітації в цілому, друга група запитань стосується організації відновного лікування та реабілітації в конкретних закладах. Так, перша група запитань $(1,3,4,5,8)$ стосується організації відновного лікування в цілому, і дає можливість визначити рівень інформованості лікарів щодо принципів формування реабілітаційних програм, а також прихильність лікарів до організації відновного лікування та реабілітації. Друга група запитань $(2,6,7,9)$ стосується організації відновного лікування у тих закладах, де працюють лікарі, і дає можливість визначити рівень організації відновного лікування та реабілітаційної допомоги в конкретних закладах. Рівень прихильності лікарів клініцистів (перша група запитань) визначається по кожному питанню трьома можливими категоріями: рівень прихильності високий, помірний чи низький (табл. 2). Сумарне визначення рівня прихильності шляхом розділення відповіді за рівнем прихильності, i співвіднесення кількість відповідей кожного рівня 3 кількістю опитаних лікарів. Оскільки перша група в анкеті містить 5 запитань, рівень прихильності буде оцінюватись за 5-бальною шкалою, максимальний рівень прихильності становитиме 5 балів.

Таблиия 2

Методика обчислення рівня прихильності лікарів до відновного лікування

\begin{tabular}{|c|}
\hline $\begin{array}{c}\text { № запитання } \\
\text { 3ершої групи } \\
\text { запитань }\end{array}$ \\
\hline 1 \\
\hline 3 \\
\hline 4 \\
\hline 5 \\
\hline 8 \\
\hline
\end{tabular}

Рівень прихильності

\begin{tabular}{|c|}
\hline $\begin{array}{c}\text { Кількість } \\
\text { відповідей, які } \\
\text { відображають } \\
\text { високий рівень } \\
\text { прихильності }\end{array}$ \\
\hline $\mathrm{B} 1$ \\
\hline $\mathrm{B} 2$ \\
\hline B3 \\
\hline B4 \\
\hline B5 \\
\hline
\end{tabular}

Сума B1:B5 N

\begin{tabular}{|c|}
\hline Кількість \\
відповідей, які \\
відображають \\
помірний рівень \\
прихильності
\end{tabular}

$\Pi 1$

П2

П3

$\Pi 4$

$\Pi 5$

\begin{tabular}{|c|}
\hline Кількість \\
відповідей, які \\
відображають \\
низький рівень \\
прихильності
\end{tabular}

H1

$\mathrm{H} 2$

$\mathrm{H} 3$

H4

H5

\begin{tabular}{|c|}
\hline $\begin{array}{c}\text { Всього опитано } \\
\text { лікарів (N) }\end{array}$ \\
\hline $\mathrm{B} 1+\Pi 1+\mathrm{H} 1=\mathrm{N}$ \\
\hline $\mathrm{B} 2+\Pi 2+\mathrm{H} 2=\mathrm{N}$ \\
\hline $\mathrm{B} 3+\Pi 3+\mathrm{H} 3=\mathrm{N}$ \\
\hline $\mathrm{B} 4+\Pi 4+\mathrm{H} 4=\mathrm{N}$ \\
\hline $\mathrm{B} 5+\Pi 5+\mathrm{H} 5=\mathrm{N}$ \\
\hline
\end{tabular}

Кожна відповідь другої групи запитань анкети оцінювалась 3 точки зору повноти реалізації певного аспекту відновного лікування за трьома наступними категоріями: позитивно, негативно та частково. Аналогічно 3 першою групою запитань, щоб обчислити ефективність організації відновного лікування у закладах, ми розділити відповіді за характеристиками, і співвіднесли кількість відповідей кожного рівня 3 кількістю опитаних лікарів. Оскільки друга група в анкеті містить 4 запитання, рівень прихильності буде оцінюватись за 4-бальною шкалою, максимальний рівень прихильності становитиме 4 бали.

\section{Результати дослідження та їх обговорення}

Всього проведено опитування 70 лікарівспеціалістів третинного рівня надання медичної допомоги населенню. В дослідженні взяли участь лікарі таких спеціальностей: за профілем «нейрореабілітація» 10 лікарів-невропатологів; за профілем «м'язово-скелетна реабілітація» проведено опитування 8 лікарів травматологів-ортопедів; за профілем «кардіопульмонарна» реабілітація проведено опитування лікарівкардіологів та торакальних хірургів - всього 12 лікарів; за профілем «медико-психологічна реабілітація учасників антитерористичної операції» проведено опитування 8 лікарів-психологів та психіатрів; за профілем «реабілітація після оперативних втручань на органах зору» проведено опитування 8 лікарів-офтальмологів; за профілем «реабілітація при порушенні перебігу вагітності» (ускладнена вагітність) проведено опитування 10 акушер-гінекологів та 14 лікарів за профілем «інша (соматична) реабілітація». 
На першому етапі нами було вивчено рівень інформованості лікарів щодо принципів формування реабілітаційних програм. 3 цією метою нами проведено аналіз відповідей респондентів на запитання першої групи. Загалом результати аналізу відповідей усіх респондентів на питання анкети першої групи представлено у таблиці 3.

Як видно з таблиці 3, загальний рівень прихильності опитаних лікарів до відновного лікування та необхідності реабілітаційної допомоги загалом є достатньо високим. По окремим питанням першої групи усі респонденти надали відповіді, які демонструють максимальний рівень прихильності. Так, усі опитані лікарі третинного рівня надання медичної допомоги вважають, що знайомі 3 принципами організації відновного лікування хворих та формуванням реабілітаційних програм. Хоча, лише $10(14,3 \%)$ з опитаних лікарів уточнили, що можуть самостійно сформувати ефективну програму реабілітації. Одностайними респонденти були і у відповіді на запитання №8: оцінювати ефективність медичної реабілітації повинні всі учасники програми. Це є ознакою готовності опитаних лікарів-клініцистів до командної роботи, з залученням до процесу як спеціалістів реабілітації, так і пацієнта та осіб з його оточення.

Табличя 3

Розподіл відповідей за категоріями та підсумковий рівень прихильності респондентів до організації відновного лікування та реабілітації загалом

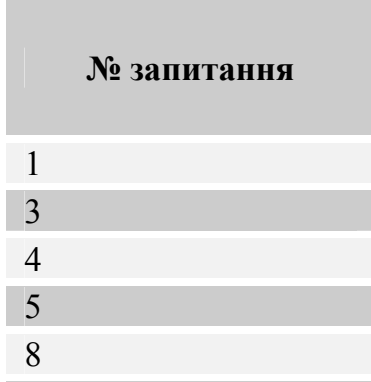

Прихильність, бал

\begin{tabular}{|c|c|}
\hline \multicolumn{2}{|c|}{ Високий } \\
\hline абс. & $\%$ \\
\hline 70 & 100,0 \\
\hline 50 & 71,4 \\
\hline 56 & 80,0 \\
\hline 54 & 77,1 \\
\hline 70 & 100,0 \\
\hline \multicolumn{2}{|c|}{4,29} \\
\hline
\end{tabular}

Щоб оцінити рівень прихильності по кожній спеціальності, було обраховано середній бал із 5-ти відповідей по кожному спеціалісту та по групі «інші». Наприклад, серед лікарів різних спеціальностей, що входять до категорії «інші», зафіксовано 46 відповідей, що відображають високу прихильність. Всього опитано 14 лікарів, тому рівень високої прихильності становитиме 46:14=3,3. Відповідей, що відображають помірну прихильність, серед лікарів цієї категорії отримано 20 , i оскільки опитано 14 лікарів, показник помірної прихильності становитиме 20:14=1,4. Про низьку прихильність свідчить 2 відповіді, тому показник низької прихильності становитиме 2:14=0,1.

Аналогічним чином обчислюємо рівень прихильності до відновного лікування та реабілітації по кожній спеціальності (невропатологи, кардіологи, торакальні хірурги, офтальмологи, психіатри, психотерапевти, акушер-гінекологи, травматологи). Результати представлено на рисунку.

Як видно з рисунку, найбільший показник високої прихильності констатовано серед кардіологів (4,3 бали), невропатологів (4,2 бали) та акушер-гінекологів (4 бали). В той же час, серед офтальмологів переважає помірна прихильність - на рівні 2,5 балів; при тому що показник високої прихильності нижчий, і становить 2,3 бали. Серед психіатрів показники високої та помірної прихильності відрізняються не суттєво: висока прихильність становить 2,8 балів, помірна - 2,3 бали. Причини різної прихильності можуть бути різними. Наприклад, лікарі-невропатологи постійно спостерігають неврологічні порушення, які піддаються корекції в процесі реабілітації, i тому

\section{Рівень прихильності}

\begin{tabular}{r|r|r|}
\multicolumn{2}{c}{ Помірний } & \multicolumn{2}{c}{ Низький } \\
абс. & $\%$ & абс.
\end{tabular}

$0 \quad 0$

20

10

12

28,6

14,3

17,2

0

0

0,60

\begin{tabular}{c|c|}
\hline 0 & 0 \\
\hline 0 & 0 \\
\hline 4 & 5,7 \\
\hline 4 & 5,7 \\
\hline 0 & 0 \\
\hline
\end{tabular}

0,11 прихильність висока. Лікарям-кардіологам важко недооцінити важливість реабілітації, контингент їхніх хворих підлягає реабілітації в санаторно-курортних закладах за спеціальними програмами, які історично використовуються відносно тривалий період часу. Причина недостатньої прихильності лікарів-психіатрів, психологів також може бути обумовлена традиціями, що склалися історично - хворі даного профілю ізолювалися від загального контингенту, їх реабілітація за загальними підходами була затруднена. Щодо лікарів офтальмологів причина може бути в тому, що процеси реабілітації хворих даного профілю мають свої особливості.

Взагалі рівень інформованості лікарів можна вважати достатньо високим, оскільки всі без винятку визнають важливу роль відновного лікування та реабілітації. 85,7\% лікарів інформовані щодо формування реабілітаційних програм, але не можуть їх самостійно скласти. Понад 70\% лікарів дотримуються думки, що реабілітацію слід поєднувати 3 клінічним лікуванням. Понад $80 \%$ визнають провідну роль спеціалістареабілітолога у призначенні відновного лікування або реабілітаційної програми.

Аналіз відповідей респондентів на питання анкети другої групи, які відображають оцінку лікарями стану організації відновного лікування та реабілітації у тих закладах, де вони працюють - вона дає можливість зробити заключення про стан впровадження реабілітаційних програм безпосередньо в діяльність закладів охорони здоров'я третього рівня надання медичної допомоги. Нами проводилась оцінка повноти реалізації певного аспекту відновного лікування та 
реабілітаційних послуг за трьома наступними категоріями: «так, повна», «ні, відсутня» та «частково забезпечено». Загальний рівень ефективності організації в закладі відновного лікування та реабілітації оцінювався за 4-бальною шкалою. Результати аналізу відповідей респондентів щодо рівня ефективності організації відновного лікування та реабілітації у закладах охорони здоров'я, де вони працюють наведено в таблиці 4.

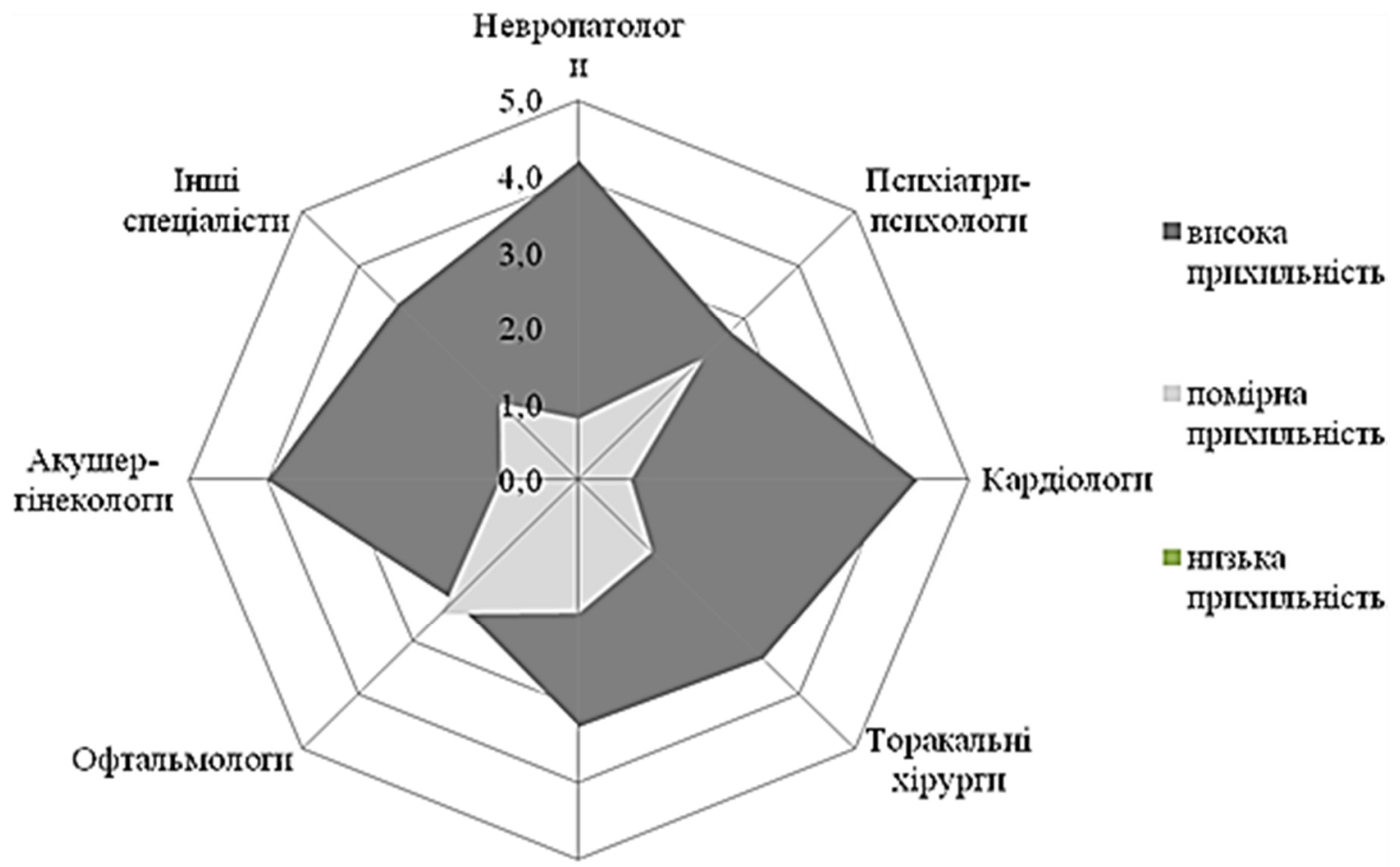

Травматологіг

Рис. Рівень прихильності лікарів різних спеціальностей до відновного лікування

Таблиия 4

Розподіл відповідей за категоріями та оцінка рівня ефективності організації відновного лікування та реабілітації у закладах охорони здоров'я

\begin{tabular}{|c|c|c|c|c|c|c|}
\hline \multirow{3}{*}{ № запитання } & \multicolumn{6}{|c|}{$\begin{array}{c}\text { Кількість відповідей за категоріями оцінки повноти реалізації } \\
\text { аспекту відновного лікування або реабілітації }\end{array}$} \\
\hline & \multicolumn{2}{|c|}{ Так, повна } & \multicolumn{2}{|c|}{ Ні, відсутня } & \multicolumn{2}{|c|}{ Частково забезпечено } \\
\hline & абс. & $\%$ & абс. & $\%$ & абс. & $\%$ \\
\hline 2 & 0 & 0 & 2 & 2,9 & 68 & 97,1 \\
\hline 6 & 6 & 8,6 & 4 & 5,7 & 60 & 85,7 \\
\hline 7 & 6 & 8,6 & 0 & 0 & 64 & 91,4 \\
\hline 9 & 0 & 0 & 0 & 0 & 70 & 100,0 \\
\hline $\begin{array}{l}\text { Ефективність } \\
\text { організації, бал }\end{array}$ & \multicolumn{2}{|c|}{0,17} & \multicolumn{2}{|c|}{0,08} & \multicolumn{2}{|c|}{3,74} \\
\hline
\end{tabular}

Як видно з таблиці 4, за оцінками респондентів, в цілому рівень ефективності організації відновного лікування i реабілітації у закладах можна охарактеризувати як такий, що потребує покращення. Так, лише 6,8\% респондентів вважає, що в закладах де вони працюють достатнє охоплення пацієнтів медичною реабілітацією та достатня кількість фахівців, які іiі забезпечують. В результаті, оцінка рівня ефективності організації відновного лікування та реабілітації у закладах охорони здоров'я третього рівня лікарями визначена 3,74 бали 34 максимально можливих за категорією «часткового забезпечення певного аспекту відновного лікування та реабілітаційних послуг».

Загальну характеристику можна сформулювати таким чином: на думку лікарів, система відновного лікування та реабілітації в закладах охорони здоров'я, де вони працюють, потребує вдосконалення, оскільки охоплення пацієнтів медичною реабілітацією у закладі 
недостатнє, застосовуються тільки певні елементи відновного лікування та кількість фахівців слід збільшити.

\section{Висновки}

За результатами проведеного дослідження серед лікарів-клініцистів різних спеціальностей третинного рівня надання медичної допомоги можна зробити наступні висновки:

1. Загальний рівень прихильності опитаних лікарів до відновного лікування та необхідності реабілітаційної допомоги загалом є достатньо високим. Так, усі опитані лікарі третинного рівня надання медичної допомоги вважають, що знайомі 3 принципами організації відновного лікування хворих та формуванням реабілітаційних програм. Хоча, лише 10 (14,3\%) 3 опитаних лікарів уточнили, що можу самостійно сформувати ефективну програму реабілітації. Одностайними респонденти були і у відповіді на запитання, яке відображало готовність опитаних лікарівклініцистів до командної роботи, з залученням до процесу як спеціалістів реабілітації, так і пацієнта та осіб $з$ його оточення. Найбільший показник високої прихильності констатовано серед кардіологів (4,3 бали із 5 максимально можливих), невропатологів (4,2 бали) та акушергінекологів (4 бали).

2. Взагалі рівень інформованості лікарів можна вважати достатньо високим, оскільки всі без винятку визнають важливу роль відновного лікування та реабілітації. Зокрема, 85,7\% опитаних лікарів інформовані щодо формування реабілітаційних програм, але не можуть їх самостійно скласти. Понад $70 \%$ респондентів дотримуються думки, що реабілітацію слід поєднувати 3 клінічним лікуванням. Понад $80 \%$ визнають провідну роль спеціаліста-реабілітолога у призначенні відновного лікування або реабілітаційної програми.

3. Оцінка рівня ефективності організації відновного лікування та реабілітації у закладах охорони здоров'я третього рівня лікарями визначена 3,74 бали 3 4-х максимально можливих за категорією «часткового забезпечення певного аспекту відновного лікування та реабілітаційних послуг». Загалом, на думку опитаних лікарів, система відновного лікування та реабілітації в закладах охорони здоров'я, де вони працюють, потребує вдосконалення, оскільки охоплення пацієнтів медичною реабілітацією у закладі недостатнє, застосовуються тільки певні елементи відновного лікування та кількість фахівців слід збільшити.

Перспективи подальших досліджень полягають у подальшому розвитку кількох напрямків. Визначення рівнів прихильності та інформованості щодо відновного лікування та реабілітації лікарів клініцистів в закладах охорони здоров'я вторинного і первинного рівня надання медичної допомоги. Поглиблене вивчення рівня знань та вмінь і окремих компетентностей в питаннях ранньої реабілітації та відновного лікування практикуючих лікарів різних спеціальностей.

\section{Література}

1. Вакуленко Л.О. Шляхи удосконалення фізичної реабілітації в Україні / Л. О. Вакуленко, Д. В. Вакуленко, О. Р. Барладин, С. 3. Храбра, В. С. Грушко // Вісник наукових досліджень. - 2016. - № 3. - С. 92-93.

2. Шевчук В. Медико-соціальні пазли для інвалідів / В. Шевчук // Ваше здоров’я. - 2015. - № 31-32. - С. 12-13.

3. Організація відновного лікування на рівні первинної медико-санітарної допомоги : Методичні рекомендації / В. М. Лобас, Г.О. Слабкий, О.А. Кравець. - Київ, 2013. - 35 с.

4. Мельник В.П. Законодавчі засади правового регулювання реабілітації інвалідів: сучасний стан та напрями удосконалення / В. П. Мельник // Часопис Національного університету "Острозька академія". Сер. : Право. - 2014. № 2 [Електронний ресурс]. - Режим доступу: http://nbuv.gov.ua/UJRN/Choasp_2014_2_22. - Назва 3 екрану.

Дата надходження рукопису до редакиії: 23.09.2019 р.

Результаты изучения мнения врачей третичного уровня оказания медицинской помощи по отдельным вопросам организации реабилитационной помощи пациентам в учреждениях здравоохранения

Пензеник О.А., Миронюк И.С., Кручаница В.В. ГВУЗ «Ужгородский национальный университет», г. Ужгород, Украина

Цель исследования - изучение мнения практикующих врачей различных специальностей третичного уровня оказания медицинской помощи по их отношению к реабилитации пациентов в учреждениях здравоохранения, где они работают и оценки эффективности организации данного направления работы

Объект и методы исследования. Объектом исследования выступила система организации реабилитационной помощи пациентам в учреждениях здравоохранения третичного уровня оказания медицинской помощи в Закарпатской области. Методы исследования: системный подход и системный анализ; социологический метод, статистический метод.

Результаты. По результатам проведенного опроса 70 врачей-специалистов выявлено, что все знакомы с принципами организации восстановительного лечения больных и формированием реабилитационных программ. 
Хотя, лишь 14,3\% опрошенных врачей признают способность самостоятельно сформировать эффективную программу реабилитации. Самые высокие уровни понимания и приверженности к необходимости внедрения программ реабилитации в учреждениях, где они работают проявили кардиологи, невропатологи и акушер-гинекологи (4,0-4,3 балла из 5 возможных). Оценка уровня эффективности организации восстановительного лечения и реабилитации в учреждениях здравоохранения врачами определена 3,74 балла из 4 максимально возможных по категории «частичного обеспечения определенного аспекта восстановительного лечения и реабилитационных услуг».

Выводы. Общий уровень приверженности опрошенных врачей к восстановительному лечению и необходимости реабилитационной помощи целом является достаточно высоким. По мнению опрошенных врачей, система восстановительного лечения и реабилитации в учреждениях здравоохранения, где они работают, нуждается в совершенствовании.

Ключевые слова: реабилитационная помощь, учреждения здравоохранения третичного уровня, социологическое исследование, врачи различных специальностей.

Results of the study of the opinion of the doctors of tertiary level medical care on certain issues of organizing rehabilitation care for patients in health care institutions

Penzenyk O.A., Myronyuk I.S., Kruchanytsia V.V. Uzhhorod National University, Uzhhorod, Ukraine

Goal of research - to study the opinion of practitioners of various specialties of tertiary-level medical care on patient's rehabilitation in health care institutions where they work and assessment of the effectiveness of organizing this direction of activity.

Object and methods of research. The system of organizing rehabilitation care for patients in tertiary health care institutions in Transcarpathian region became the object of study. Methods of research: system approach and system analysis; sociological method, statistical method.

Results. According to the results of the survey of 70 doctors-specialist, it was revealed that everyone is familiar with the principles of the organization of rehabilitation treatment of patients and the formation of rehabilitation programs. Although, only $14.3 \%$ of the doctors surveyed recognize the ability to independently develop an effective rehabilitation program. The highest levels of understanding and commitment to the need for implementing rehabilitation programs in the institutions where they work were shown by cardiologists, neurologists and obstetricians-gynecologists (4.0-4.3 points out of 5 possible). Assessment of the effectiveness of rehabilitation treatment organization and rehabilitation in health care institutions by the doctors determined 3.74 points out of 4 maximally possible in the category of "partial provision of certain aspect of rehabilitation treatment and rehabilitation services".

Conclusions. The overall level of commitment of the doctors interviewed to rehabilitation treatment and the need for rehabilitation care as a whole is quite high. According to the opinion of doctors interviewed, the system of rehabilitation treatment and rehabilitation in health care institutions where they work needs improving.

Key words: rehabilitation care, tertiary level health care institutions, sociological study, doctors of various specialties.

\section{Відомості про авторів}

Пензеник Ольга Андріївна - магістр фізичної терапії, ДВНЗ «Ужгородський національний університет», м. Ужгород, пл. Народна, 3.

Миронюк Іван Святославович - доктор медичних наук, доцент, декан факультету здоров'я та фізичного виховання ДВНЗ «Ужгородський національний університет», м. Ужгород, пл. Народна, 3.

Кручаниця Василь Васильович - кандидат медичних наук, доцент кафедри наук про здоров’я ДВНЗ «Ужгородський національний університет», м. Ужгород, пл. Народна, 3. 